Florida International University FIU Digital Commons

3-13-2002

\title{
D.H. Lawrence and civilization: a study of D.H. Lawrence's "leadership" novels, Aaron's rod, Kangaroo and the plumed serpent
}

Nader Elhefnawy

Florida International University

DOI: $10.25148 /$ etd.FI15101287

Follow this and additional works at: https://digitalcommons.fiu.edu/etd

Part of the Literature in English, British Isles Commons

\section{Recommended Citation}

Elhefnawy, Nader, "D.H. Lawrence and civilization: a study of D.H. Lawrence's "leadership" novels, Aaron's rod, Kangaroo and the plumed serpent" (2002). FIU Electronic Theses and Dissertations. 3135.

https://digitalcommons.fiu.edu/etd/3135 


\section{FLORIDA INTERNATIONAL UNTVERSITY}

Miami, Florida

\section{D.H. LAWRENCE AND CIVILIZATION: A STUDY OF D.H. LAWRENCE'S "LEADERSHIP" NOVELS, AARON'S ROD, KANGAROO AND THE PLUMED SERPENT}

A thesis submitted in partial fulfillment of the requirements for the degree of MASTER OF ARTS in ENGLISH by

Nader Elhefnawy 
To: Dean Arthur Herriott

College of Arts and Sciences

This thesis, written by Nader Elhefnawy, and entitled D.H. Lawrence and Civilization: A Study of D.H. Lawrence's "Leadership" Novels, Aaron's Rod, Kangaroo and The Plumed Serpent, having been approved in respect to style and intellectual content, is referred to you for judgment.

We have read this thesis and recommend that it be approved.

Maneck Daruwala

Butler Waugh

Date of Defense: March 13, 2002

Phillip Marcus, Major Professor

The thesis of Nader Elhefnawy is approved.

Dean Arthur Herriott College of Arts and Sciences

Dean Douglas Wartzok University Graduate School

Florida International University, 2002 


\begin{abstract}
OF THE THESIS
D.H. LAWRENCE AND CIVILIZATION: A STUDY OF D.H. LAWRENCE'S

"LEADERSHIP" NOVELS, AARON'S ROD, KANGAROO AND THE PLUMED

SERPENT

by
\end{abstract}

Nader Elhefnawy

Florida International University, 2002

Miami, Florida

Professor Phillip Marcus, Major Professor

D.H. Lawrence's "leadership" novels, namely Aaron's Rod, Kangaroo and The Plumed Serpent, dealt with the ramifications of industrial civilization. This thesis uses a "Tofflerian" approach, drawing on the works of the futurist Alvin Toffler's "trilogy" of noted books on the rate, direction and consequences of "civilizational" change, Future Shock, The Third Wave and Powershift. This thesis argues that Lawrence recognizes the demise of the "love-urge" that had sustained civilization in Aaron's Rod; seeks and fails to find a solution in the political movements of his time in Kangaroo, demonstrating the impossibility of a modern solution to inherently modern problems; and in The Plumed Serpent, seeks an answer in a way of life apart from industrial civilization entirely. 


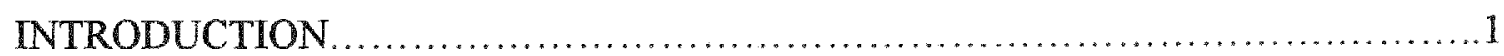

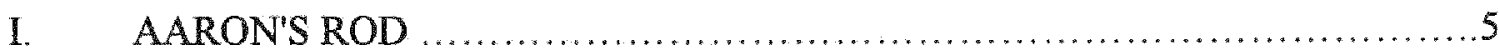

Second Wave Civilization in Aaron's Rod ..................................5

The Love-Urge and the Power Soul ........................................... 10

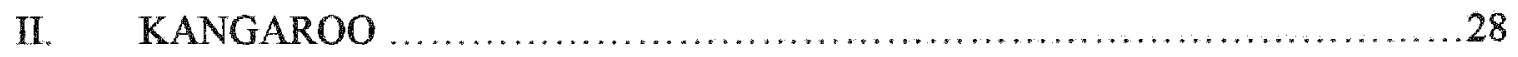

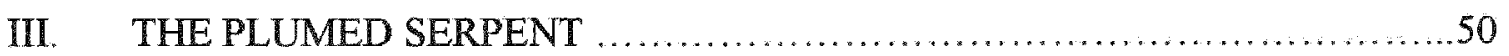

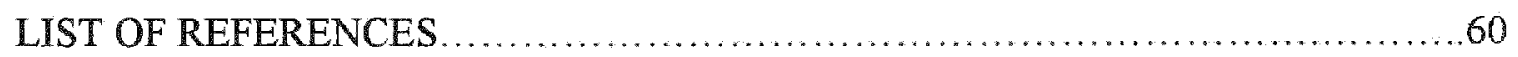




\section{INTRODUCTION}

D.H. Lawrence's works are today remembered as a celebration of the natural and whole human being, but also as a criticism of the modern industrial society that he believed made such wholeness difficult or impossible to achieve. These novels tended to balance a focus on individual men and women with a broader concern for society and civilization as a whole, as in The Rainbow or Women in Love. Lawrence's broader concerns were, however, foregrounded in what have been called by some Lawrence's trilogy of "power" or "leadership" novels, namely Aaron's Rad, Kangaroo and The Plumed Serpent.

It is the purpose of this thesis to examine these three novels with an eye to Lawrence's views on the present and possible directions of civilization in general from his historical vantage point of the 1920s. A "civilizational" approach is one which takes "civilization" (rather than, for instance, an individual or country), however defined, as a unit of analysis. Numerous such approaches exist, "civilization" having been studied by philosophers, historians and other scholars as diverse as Arnold Toynbee, William McNeill and Samuel Huntington. Consequently, it can encompass a broad variety of subjects, ranging from intellectual history to political science to technology. The particular subject of concern here will be Lawrence's critique of industrial civilization, and his search for an escape from the conundrums it posed.

The specific approach being taken in this thesis will be "Tofflerian", drawing on the works of the futurist Alvin Toffler's "trilogy" of noted books on "civilizational" change, 
Future Shock, The Third Wave and Powershift. Toffler described three types of civilization in the above-mentioned works, First Wave, Second Wave and Third Wave, each defined by their mode of economic production, and on which was also founded their value system and way of life. First Wave civilizations were essentially agricultural. Second Wave civilizations were "smoke-stack" industrial. Third Wave civilizations are "post-industrial", or "information-based".

Toffler's work, which has been an important influence on fields ranging from business management to military science in the past three decades, has been largely ignored by literary scholars. However, the fact that he analyzes industrial civilization and takes an interest in the psychological problems it poses, means that he dealt with the same issues as Lawrence from a different perspective, making his studies not merely relevant but a promising new basis for studying Lawrence's writings.

Such an analysis is of course fraught with potential pitfalls, not the least of which is Lawrence's frequently obscure terminology, and to paraphrase critic Horace Gregory, his contentment with contradicting himself at every turn. ${ }^{1}$ More importantly, where Toffler is a materialist who rejects the notion of an essential human nature, Lawrence's focus is on the spiritual. Nonetheless, Lawrence's spiritual concerns are undeniably linked to the material effects of industrial civilization, and Toffler considers the material forces he studies to be the shapers of the psychology, philosophy and spirituality of the societies he analyzes.

${ }^{1}$ Horace Gregory, D.H. Lowrence: Pilgrim of the Apocalypse (New York: Grove Press, 1933) 68. 
Following this introduction, chapter one will examine Aaron's Rod. Chapters two and three will examine Kangaroo and The Plumed Serpent respectively. The approach undertaken to these novels will be a close reading of the texts informed by the theoretical approach described above, as well as the broader body of Lawrencian literary criticism. As all three novels share many of the same themes, the principal difference between them is in emphasis and the degree to which Lawrence had developed those themes, ideas first exhibited in an earlier book becoming clearer in a later one, so that the chapters will emphasize the focus of each novel, and bring in points from other novels relevant to that focus, rather than examining each book in isolation.

This thesis regards the three works as a set, taking seriously their categorization as a "trilogy" of novels which, to quote critic John Vickery, "signifies the recognition of a cultural and personal dead-end, of a crisis that spells the nullity of human life, and with this the individual's quest for a new and truly human mode of existence. ${ }^{22}$ The Second Wave civilization that Alvin Toffler described is market-centered, founded on "brute force" technology and accordingly, the principles of standardization, specialization, synchronization, concentration, maximization and centralization. ${ }^{3}$ In Lawrencian terms, it is, for all of its mechanistic qualities, a civilization of what Lawrence saw as an exhausted love-urge, making spiritual wholeness impossible within its framework.

In particular, it is the position of this thesis that Lawrence moves from a recognition of what he sees as the principal problem of his civilization (the demise of the love-urge) in

2 John Vickery, "The Plumed Serpent and the Eternal Paradox" Criticism: A Quarterly for Literature and the Arts. 1963; 119-134.

${ }^{3}$ Alvin Toffler, The Third Wove (New York: Bantam Books, 1981) 37-60. 
Aaron's Rod, focusing on its effects at the level of his protagonist Aaron Sisson; seeks and fails to find a solution in the political movements of his time in Kangaroo, demonstrating the impossibility of finding a Second Wave solution to problems that are inherent to Second Wave civilization; and in The Plumed Serpent, the novel in which his themes are developed most fully and clearly, appears to find a solution in a cult celebrating the power-urge and sanctifying the "dark gods", a way of life entirely outside the Second Wave framework. 
In Aaron's Rod, there is on the one hand a sense of dissatisfaction with mass, industrialized society, and on the other, a dawning recognition of what Lawrence terms the "love" and "power" urges. The connection between the two has yet to become as explicit or as fully developed as it would be in later Lawrence novels, like Kangaroo and The Plumed Serpent, though Lawrence does identify his "diseased" civilization with the exhaustion of the love-urge. Lawrence's notions of an alternative mode of living which can give concreteness to this principle remain ill-defined, though it is clear that the path to revitalization lies through the power-urge that has been for so long ignored.

\section{SECOND WAVE CIVILIZATION IN AARON'S ROD}

Lawrence sees little hope of salvation through the ideologies of his time, Left or Right, rejecting the super-ideology on which they are both founded, beginning with the notion of progress. A "core belief" and justification of industrial society, Toffler writes, "was the progress principle - the idea that history flows irreversibly toward a better life for humanity", an "optimism that saw each scientific breakthrough or 'new improved product' as evidence of an inevitable advance toward human perfection." ${ }^{5}$

\footnotetext{
${ }^{4}$ Alvin Toffler, The Third Wave, 101.

${ }^{5}$ Toffler, The Third Wave, 294.
} 
Of course, Second Wave principles met with resistance in Britain as elsewhere, and Paul Delany has made the argument that it was the First Wave opponents of industrialism who won the cultural struggle. ${ }^{6}$ These proponents of what Delany terms the "rural myth" assumed "that industry and urbanization have no moral basis; they express only a materialism without aim or limit." Consistent with a belief in this "rural myth", Rawdon Lilly flatly rejects the idea of a "logical progression in human social activity", the notion that "human society through the course of ages only enacts, spasmodically but still inevitably, the logical development of a given idea. ${ }^{8}$ While he concedes to Levison that some form of socialism may be logically inevitable, he also rejects logic, which in his view may as well be used for "lavatory" paper.

Italy appeals to Aaron Sisson precisely because it has "progressed" less far than the more thoroughly industrialized societies of Northern Europe in general, and his native England in particular. What a Levison may view as a lower level of economic and social development, Aaron regards as the country's being less damaged by the "disease" of "horrible sameness", the "accursed mechanical ideal" (in other words the standardization and synchronization so much a part of Second Wave civilization). ${ }^{9}$ The English capital of London, the scene of the mechanical ideal's furthest advance, impresses not with its sophistication, but with "the silliness of the people who inhabit it and the boring nature of

\footnotetext{
${ }^{6}$ Paul Delany, "Lawrence and the Decline of the Industrial Spirit" Ed. Michael Squires and Keith Cushman, The Challenge of D.H. Lawrence (Madison, Wisconsin: $\mathrm{U}$ of Wisconsin P, 1990) 78 .

${ }^{7}$ Delany, 79.

${ }^{8}$ D.H. Lawrence, Aaron's Rod (Cambridge: Cambridge UP, 1988) 280.
} 
their social diversions ${ }^{10}$, so evident in the scenes where they play with the idea of bloody revolution ${ }^{11}$, which suffuses the text with a sense of weary disenchantment with modern shallowness ${ }^{12}$. By comparison, the sight of Florentine farmers with their "curious individuality", "subtle fearlessness" and "challenge of the unquenched human soul" - the sight of men "who existed without apology and without justification", and therefore "the rarest thing left in our sweet Christendom" - makes Aaron feel a "new life-urge rising inside of himself." ${ }^{13}$

After all, Lawrence observes, life is not yet "just a business proposition" for them, and his use of that phrase is telling, as Lawrence frequently laments the corrosion of human relationships by money, and the centrality of market values. It is with sadness that Aaron realizes that "money is the "only authority left"14, class superiority having become nothing more than a trick, which made the "upper middle classes . . Eton and Oxford" hold on to it "all the more intensely." 15 The sentiment is echoed by Lilly when he considers how people "don't care how much power the mob has over them, the nation, Lloyd George and Northcliffe and the police and money. They'll yield themselves to that sort of power quickly enough" while being incapable of submitting to what he sees as a

\footnotetext{
${ }^{9}$ Lawrence, Aaron's Rod, 152-153.

${ }^{10}$ Alastair Niven, D.H. Lowrence: The Novels (Cambridge: Cambridge UP, 1978$) 135$.

${ }^{11}$ Frank Kermode, D.H. Lawrence (London: Fontana, 1973) 82.

${ }^{12}$ Niven, 138 .

${ }^{13}$ Lawrence, Aaron's Rod, 212-213.

${ }^{14}$ Lawrence, Aaron's Rod, 136.
} 
"bit of healthy individual authority." ${ }^{16}$ Much of the disenchantment with Labor and socialism that Lawrence expresses has to do with his perception that socialism as much as capitalism reflects industrialism's "obsessive concern with money, goods and things. "17

Lawrence's objection to the First World War is also, at bottom, only a rejection of the form of warfare he knew in his own time, which took the process of "industrial-style rationalization" Lawrence so hated to its "ultimate" extreme. ${ }^{18}$ While Lilly says that he would like to kill his enemies, "become a bit of that huge obscene machine they called the war", to become part of that standardized mass, in other words, was unthinkable to him. ${ }^{19}$ In fact, Lilly goes on to blame the mass character of modern society for the ugliness of mechanized warfare: "No man who was awake and in possession of himself would use poison gases: no man ... It's only when the ghastly mob-sleep, the dream helplessness of the mass-psyche overcomes him, that he becomes completely base and obscene. ${ }^{120}$

Nevertheless, Lilly does not believe in turning back the clock and returning to an agrarian, First Wave mode of existence, either by returning to the land in England. To lump Lilly and Aaron in with the traditionalist interest groups, "landed and financial

${ }^{15}$ Lawrence, Aaron's Rod, 197.

${ }^{16}$ Lawrence, Aaron's Rod, 96-97.

${ }^{17}$ Toffler, The Third Wave, 41.

${ }^{18}$ Ibid.

${ }^{19}$ Alvin and Heidi Toffler, War and Ant-War (New York: Little, Brown \& Co., 1993) $39-40$.

${ }^{20}$ Lawrence, Aaron's Rod, 119. 
interests over industrial ones, of the rentier over the manager", would be simplistic. ${ }^{21}$ Both men "have a wary, self-defiant attitude toward the ruling classes, the classes that had won a footing through money power or the accident of birth" ${ }^{\prime 22}$, so that many of the values sacred to British traditionalists were anathema to them. When Lawrence laments the disappearance of all authority not based on money, he also evinces little sympathy with the shabby gentility of the landed gentry, let alone promoting their class interests. ${ }^{23}$

Nor is it possible for them to simply leave behind the industrialized regions of the world for places where more traditional lifestyles endure. Lawrence, for instance, is not optimistic about the prospects for the Florentine peasants he so admires, seeing the "power of industry . . . as the only real force in civil society - something demonic and overwhelming that would expand, without effective resistance, until it reached a destructive consummation." 24 Italy would someday become like England, and the rest of the world was hardly more attractive. "There's a whole world besides this little gang of Europeans" Lilly thinks, but finds little heart in that fact:

I can't do with folk who teem by the billion, like the Chinese and Japs and orientals together ... the flea-bitten Asiatics - Even niggers are better than Asiatics, though they are wallowers ... All . . are craven - Europeans, Asiatics, Africans - everyone at his own individual quick and craven and cringing: only conceited in the mass, the mob. ${ }^{25}$

${ }^{21}$ Delany, 78 .

${ }^{22}$ Gregory, 52-53.

${ }^{23}$ Alvin Toffler, Powershift (New York: Bantam Books, 1990) 10-11.

${ }^{24}$ Delany, 83 .

${ }^{25}$ Lawrence, Aaron's Rod, 97. 
For Lilly, all of these peoples were simply too numerous, too "massive", mass being the principle he rejected to the point of saying that "Higher types breed slower". Lilly thinks that he "would have loved the Aztecs and the Red Indians . . . they hold the element in life which I am looking for - They had living pride... The American races and the South Sea Islanders - the Marquesans, the Maori blood. That was the true blood. It wasn't frightened." However, his use of the term "would have" is critical, in that he regards it as no longer possible, the Europeans having "exterminated all the peoples worth knowing." He also looked to the wisdom of the world from before the flood, "These old Africans! And Atlantis! Strange, strange wisdom of the Kabyles! Old, old Africa, and the world before the flood!" - people killed not by the Europeans, but by their "jealous" God, at least proverbially. ${ }^{26}$

\section{THE LOVE-URGE AND THE POWER-SOUL}

Lilly identifies what he terms the love urge with "the ideal that it is better to give than to receive ... of liberty ... if the brotherhood of man ... the sanctity of human life ... goodness, charity, benevolence, public spiritedness . . sacrifice for a cause . . . unity and unanimity . . of fairness" ${ }^{27}$ It is also the love that Aaron may feel for God, women and mankind, the desire to go on "from passion to passion, from ecstasy to ecstasy, from triumph to triumph" and live "happy ever after" ${ }^{28}$ Lilly characterizes President Woodrow

\footnotetext{
${ }^{26}$ Lawrence, Aaron's Rod, 110.

${ }^{27}$ Lawrence, Aaron's Rod, 280-281.

${ }^{28}$ Lawrence, Aaron's Rod, 293-295.
} 
For Lilly, all of these peoples were simply too numerous, too "massive", mass being the principle he rejected to the point of saying that "Higher types breed slower". Lilly thinks that he "would have loved the Aztecs and the Red Indians . . . they hold the element in life which I am looking for - They had living pride ... The American races and the South Sea Islanders - the Marquesans, the Maori blood. That was the true blood. It wasn't frightened." However, his use of the term "would have" is critical, in that he regards it as no longer possible, the Europeans having "exterminated all the peoples worth knowing." He also looked to the wisdom of the world from before the flood, "These old Africans! And Atlantis! Strange, strange wisdom of the Kabyles! Old, old Africa, and the world before the flood!" - people killed not by the Europeans, but by their "jealous" God, at least proverbially. ${ }^{26}$

\section{THE LOVE-URGE AND THE POWER-SOUL}

Lilly identifies what he terms the love urge with "the ideal that it is better to give than to receive ... of liberty ... if the brotherhood of man ... the sanctity of human life ... goodness, charity, benevolence, public spiritedness ... sacrifice for a cause ... unity and unanimity . . of fairness" ${ }^{27}$ It is also the love that Aaron may feel for God, women and mankind, the desire to go on "from passion to passion, from ecstasy to ecstasy, from triumph to triumph" and live "happy ever after". ${ }^{28}$ Lilly characterizes President Woodrow

\footnotetext{
${ }^{26}$ Lawrence, Aaron's Rod, 110.

${ }^{27}$ Lawrence, Aaron's Rod, 280-281.

${ }^{28}$ Lawrence, Aaron's Rod, 293-295.
} 
Wilson as a man who "love-whooshed for humanity" and because he was acting on an urge that had been exhausted, "only got a very sorry self on his hands."

Its alternative, the power urge, is rather more nebulous, human beings having "been trying to work ourselves, at least as individuals, from the love-urge exclusively, hating the power-urge, and repressing it. ${ }^{129}$ Consequently Lilly defines it more easily in negative terms, by what it is not than by what it is. Lilly tells Aaron that it "does not seek for happiness any more than for any other state", nor does it look for justification in "God, or a creed, or a prescription." ${ }^{30}$ It is the "will-to-power - but not in Nietzche's sense. Not intellectual power. Not mental power. Not conscious will-power. Not even wisdom. But dark, living, fructifying power."

The dark, ugly character that Lilly's message may have for a human being raised to live by the love-urge is embodied in the messenger delivering it, Lilly himself. Aaron regards Lilly as "perhaps the most objectionable person to know", however "clever and attractive as he undoubtedly was", his "dark, ugly face" at the same time possessing "candour and surety" in the eyes. ${ }^{31}$ While "freak and outsider . . Lilly knew." Lilly, like the flower by the same name, is "rooted, life-central" and "cannot worry [or] . . be anxious. $^{.132}$

${ }^{29}$ Lawrence, Aaron's Rod, 297.

${ }^{30}$ Lawrence, Aaron's Rod, 296.

${ }^{31}$ Lawrence, Aaron's Rod, 289.

${ }^{32}$ Lawrence, Aaron's Rod, 166. 
Consistent with such an attitude, Lilly does not advocate one ideal more than the other. The problem is not that people have loved too much or too long, but that love has ceased to be a process and become a goal instead. ${ }^{33}$ Lawrence goes so far as to paint the relationship between Aaron and his wife Lottie in terms that are almost cannibalistic or vampiric. In a marriage, the man gives love and the woman receives "the sacramental body and spirit of the man... the blood and the body of which she has partaken become insipid or nauseous to her, she is driven mad by the endless meal of the marriage sacrament." 134

Such a relationship can not help but be destructive, and Aaron's marriage inevitably ends in hatred ${ }^{35}$, his "heart burn[ing] with a deep, deep, almost unreachable bitterness.Like a deep burn on his deepest soul. ${ }^{36}$ That hatred, however, is not in and of itself liberating, Lilly characterizing hatred as merely "the recoil of the same urge", namely the failing, exhausted love urge ${ }^{37}$ In order to truly escape it, Aaron must pass beyond hatred as well as love to find the "single oneness [that is his] destiny", and it is notable that for all of his enmities Lilly can not bring himself to hate, as when he fails to get worked up over politics. It is, as he tells Levison, simply none of his affair. ${ }^{38}$

\footnotetext{
${ }^{33}$ Ibid.

${ }^{34}$ Tbid.

${ }^{35}$ H.M. Daleski, The Forked Flame (Evanston: Northwestern UP, 1965) 192.

${ }^{36}$ Lawrence, Aaron's Rod, 264.

${ }^{37}$ Lawrence, Aaron's Rod, 294.

${ }^{38}$ Lawrence, Aaron's Rod, 280.
} 
In teaching Aaron to get beyond love and hatred, as he has already done, Lilly tells Aaron to act only on those urges that he actually feels. ${ }^{39}$ "If your soul's urge urges you to love, then love. But always know that what you are doing is the fulfilling of your own soul's impulse. It's no good trying to act by prescription . . getting into frenzies. " ${ }^{40}$ After all, Lilly teaches him,

Passion or no passion, ecstasy or no ecstasy, urge or no urge, there's no goal outside you, where you can consummate like an eagle flying into the sun, or a moth into a candle. There's no goal outside you - and . . . there's no God outside you, whom you can risk to or sink to or swoop away to. ${ }^{41}$

Since "'the ideal [of love] has ... gone dead - dead as carrion" 42 for Lilly, he looks to the "very thing we've hated", the "great dark power-urge which kept Egypt so intensely living for so many centuries" in an attempt to restore the balance.

The love-urge and the power-urge each find their analog in Alvin Toffler's theory of Second Wave civilization. According to Toffler's analysis, the "two halves of human life that the Second Wave split apart were production and consumption. ${ }^{43}$ While human beings have engaged in trade all across recorded history, most human beings produced principally for their own consumption, with an elite scraping off the surplus for their own use. However, industrialism created a situation in which "the overwhelming bulk of all

\footnotetext{
${ }^{39}$ Lawrence, Aaron's Rod, 295.

${ }^{40}$ Lawrence, Aaron's Rod, 264.

${ }^{41}$ Lawrence, Aaron's Rod, 295.

${ }^{42}$ Lawrence, Aaron's Rod, 280.

${ }^{43}$ Toffler, The Third Wave, 37.
} 
food, goods and services was destined for sale, barter or exchange. ${ }^{* 4}$ The result of this movement of the market to the center of human affairs, which the other dimensions of Second Wave society merely reflect, was that one was alternately a consumer or a producer at a given moment. More importantly, as a consumer and a producer, the individual lived by two contradictory sets of values that in effect required him to be two very different people.

The values enunciated by Lilly as belonging to the love-urge are also the values of the "productive" member of an industrialized society: "to defer gratification, to be disciplined, controlled, restrained, obedient, to be a team player." ${ }^{45}$ Such values, imparted to the individual "by family, school and boss", are what kept the machinery of an industrial civilization turning on a day-to-day basis, being necessary for everything from the smooth operation of bureaucracies to working on the shop floor of a factory or raising a family. Lawrence made the connection more explicit in Kangaroo:

"You see ... the educated world has preached the divinity of work at the lower classes... They accept the fact that nothing is divine but work: work being service and service being love ... the sacredness of work ... follows from the sacredness of love." 46

As a consumer, the individual was taught values which directly contradicted those he lived by as a producer, values which match closely with Lilly's description of the powerurge. Like Aaron, abandoning work and family, the consumer is encouraged to "seek instant gratification, to be hedonistic rather than calculating, to abandon discipline, to

\footnotetext{
${ }^{44}$ Toffler, The Third Wave, 39.

${ }^{45}$ Toffler, The Third Wave, 41.
} 
pursue individualistic pleasure. ${ }^{47}$ Where a productive member of society is supposed to behave in accordance with rational interest (whether self-interest or the "national interest") advertising assumes the consumer's irrationality, for instance.

Nonetheless, while it is possible to interpret the producer-consumer split in terms of materialistic desires, the work ethic against consumer culture for instance, it is also a psychological and even spiritual divide expressed in political and cultural forms as well as in economic life. The break between production and consumption is also the break between mental and blood- or vertebral consciousness. The producer lives for others, where the consumer seeks to satisfy only himself, which is the very essence of the powerurge. The producer creates wealth, while the consumer is a "taker", seizing the wealth of others, whether they have created it or seized it from a third party in turn.

In a world of limited means and a society of laws, average human beings found far greater scope for expressing themselves as producers rather than consumers, for making than for taking. It may seem from the perspective of a contemporary observer that no other sort of society (one which prized taking above making) could last for very long, but that has actually not been the case. Alvin Toffler observes that human beings learned to take long before they learned to make.

From the day the first paleolithic warrior smashed a rock into a small animal, violence has been used to produce wealth. . The agricultural revolution, starting some 10,000 years ago, represented a dramatic shift from taking - through fishing, foraging or hunting - to making wealth. But even agriculture was steeped in violence. Knout and knife, club and quirt were as much a part of the agricultural economy as the sickle, the scythe or the spade. ${ }^{48}$

\footnotetext{
${ }^{46}$ Lawrence, Kangaroo (Cambridge: Cambridge UP, 1994) 324

${ }^{47}$ Ibid.
} 
Civilization being equated with agriculture (which produces a food surplus, permitting permanent settlement, a specialization of social roles, etc.), all civilizations make as well as take but as Toffler explained, a pre-industrial economy is not clearly bifurcated along such lines. That is not, of course, to say that there is an obliviousness to the difference between the two activities, or that one element can not predominate above the other in a context where the split is not so fundamental.

Agrarian societies frequently celebrated the warrior, for instance, who is traditionally loyal to a charismatic leader and goes on campaign in the hope of winning glory, spoils or both. In Beowulf, Shield Sheafson is "one good king" precisely because he was a "scourge of many tribes, a wrecker of mead-benches" who made "each clan on the outlying coasts beyond the whale-road . . yield to him and . . pay tribute." In William Shakespeare's Henry $V$, there is a description of men selling off their farms - abandoning productive life - in order to follow their king to France and strike it rich there. Sir Thomas More, in Utopia, equates soldiers with robbers. By comparison, the soldier of Lawrence's era, while not productive in the same sense that a factory worker is, is seen as rendering a service and often sacrificing himself in the process, so that even he is a "maker" and a "producer" of sorts; in fact, his performance of his duties is called "national service."

This analog between the glorification of making and the glorification of taking and particular types of society, as well as what Lawrence regards as the dialectic between

${ }^{48}$ Toffler, Powershift, 36-37. 
them, is one of which Lawrence is aware, and serves as the basis of his larger philosophy of history in Kangaroo:

The mystic may stare at his own navel and try to abstract himself for ever towards Nirvana... [but] There is all the time a powerful, unconscious interplay going on between the vertebral centres of consciousness... a deep, mindless current flashing and quivering ... subject to the laws of polarity ... the outward, or downward pulse, in the great motion of sympathy or love, the love that goes out to the weaker, to the poor, to the humble. The vast, prostrate mass now becomes the positive pole of attraction: woman, the working-classes ... When the flow is power, might, majesty, glory, then it is a culminating flow towards one individual, through circles of aristocracy toward one grand centre, Emperor, Pope, Tyrant, King ... It is the grand obeisance before a master. ${ }^{49}$

In between the two extremes to which these drives, value-systems and modes of living can take an individual human being or a civilization is balance, but the interplay never stops, civilization moving back and forth between these two extremes. Lawrence sees his civilization as being at the loving, democratic end of the spectrum, and this is reflected in the practical and ethical realities of industrial civilization.

While it is demanded that the individual be a producer, one is enticed to be a consumer, and the pressure to consume was arguably less in Lawrence's time than it is today. In other words, not only was there a cleavage, but one side of life, the productive side, came to predominate over the other so completely that the spiritual or psychological value of consumption ceased to be recognized. Consistent with such an ethos, the state was in a position to make far greater demands on individuals and give them less in return than is presently the case, the state determining what its citizens may and may not read (as when it suppressed his novel The Rainbow), rationing life's necessities (to which Lawrence alludes in the first chapter of Aaron's Rod) and conscripting its citizens for

${ }^{49}$ Lawrence, Kangaroo, 302-303. 
military service, in effect calling on them to lay down their lives on its behalf. Lawrence keenly felt such repressions, having been subjected to government harassment during the First World War (about which he wrote at length in Kangaroo), while saying virtually nothing about any comparable pressure to behave irresponsibly, dropping out of the system solely to please himself. Hence, it may be said that the consuming side of an individual was repressed by the demand that he be a productive member of society, and that the emphasis on the power-urge is a revolt of the consumer against Second Wave civilization's producer ethos.

This is not, of course, to say that Lawrence was an advocate of rampant material consumerism as a way of expressing this long-denied power-urge and restoring balance to human life. The redistribution of wealth in accordance with the demands of socialism or unionists to enable individuals to consume more is not only something that would have contradicted the "Rural Myth" he and so many others in his time had expounded, but emblematic of a materialism that he explicitly and repeatedly inveighed against in principle as well as in the details. However, consumerism nonetheless appears to be one way through which that power-urge was expressed:

There seemed to have been some violent but quiet contest, a subdued fight . . . people struggling to buy things, to get things. Money was spent like water There was a wild grumbling, but a deep satisfaction in the fight, the struggle... Souls surcharged with hostility found now some outlet for their feelings. ${ }^{50}$

The exhaustion of the love-urge and the revival or rediscovery of the power-urge that made "getting" so satisfying is also observable in Aaron's change of lifestyle, an "anti-

\footnotetext{
${ }^{50}$ Lawrence, Aaron's Rod, 15.
} 
love story." At his colliery, Aaron had been not merely a miner, but a man necessarily acting on the "do-gooder" love-urge that he later learns to disdain. Superficially, his life shows the rewards that go to the productive individual: a successful member of his community, Aaron had money in the bank, a "good home" and a position of responsibility among his fellow workers. ${ }^{52}$

On closer inspection, however, his life, being lived according to the wrong principle, was falling apart. His chapter of the miners' union no longer wants him as its head and is proceeding to drive him from his post. The domestic scene to which he returns from the union meeting which makes him certain of this fact is one of "chilling lovelessness." His children are "seen struggling over the Christmas decorations, are assertive and grasping", and Aaron's wife Lottie is embittered enough that when he gives her the bad news about his post at the union, she replies "you care for nothing but a lot of ignorant colliers, who don't know what they want except it's more money for themselves . . . If you cared for your wife and children half what you care about your Union, you'd be a lot better pleased in the end." 54

Aaron's reaction to the news that he was likely to be replaced, however - the understatement that it will not break his heart - suggests his wife had misread his preoccupation with "self and politics." If the heart is taken to represent the faculty in

${ }^{51}$ Eugene Goodheart, The Utopian Vision of D.H. Lowrence, 127.

${ }^{52}$ Graham Hough, The Dark Sun: A Study of D.H. Lawrence (New York: Capricon Books, 1956) 95 .

${ }^{53}$ Niven, 134. 
human beings which loves, then Aaron can not have his heart broken simply because he no longer has one. That said, for Aaron to abandon his wife and family for his Union would be pointless, when care for his family and for his coworkers are both emotions coming out of the exhausted love-urge. Nevertheless, her sense that his feeling for their relationship was coming to an end was accurate, as is her sense that Aaron's behavior reflects a selfishness more than anything else, even if she still believes that his selfishness is something he can be brow-beaten into changing or giving up:

The familiar room, the familiar voice of his wife and his children - he felt weak as if he were dying. He felt weak like a drowning man who acquiesces in the waters. His strength was gone, he was sinking back . . He would float henceforth like a drowned man. ${ }^{55}$

When Aaron walks out on his job and his family to pursue his "picaresque" adventures, he ceases to partake in the productive side of life, and becomes solely a consumer and a taker in emotional as well as in economic terms. Aaron abandons his work as a collier, becoming a professional musician, but as a professional musician he is indifferent to seriously pursuing a career as a flautist (a position in society), earning money or adulation from others by his flute, or even devoting himself to his art. He plays as he played his flute in the kitchen of his house, for himself and himself only, unaware of and uninterested in how others feel about it for the most part, even when he accepts their patronage. (The flute is, as Lilly puts it, "Aaron's rod" because it is through this rod that he experiences his power-urge.)

\footnotetext{
${ }^{54}$ Lawrence, Aaron's Rod, 8.

${ }^{55}$ Lawrence, Aaron's Rod, 41.
} 
Aaron also abandons his wife not for another woman, but because he is tired of love, and does not want to be compelled to feel or give the love of which he is no longer capable, an action which should have been shocking but hardly ruffles the reader by the time that it happens. ${ }^{56}$ That Aaron's family is provided for financially, at least for the time being, does not change his abandonment of the love-ethic any more than his involvement with a Union did, this being a purely monetary rather than a spiritual relation, and therefore irrelevant to Lawrence's focus. Moreover, he will send his wife money only for as long as he has money to send her, and will not work to support his family anymore than he would work to support himself. ${ }^{57}$

The exhaustion is so complete, in fact, that the love-urge had ceased to be a premise for his thinking. Asked "What would the world be like if everybody lived this way?", Aaron simply replies that "Other people can please themselves."'58 Other people have ceased to exist for him as a concern, and so while satisfied by the rightness of his own actions, he can not satisfactorily explain himself to others around him. While he admits when Lottie asks him if he knows that he has treated her "vilely", he says that he supposes $\mathrm{so}^{59}$, but does not feel he had done anything actually wrong ${ }^{60}$. Of his leaving his wife, he admits that "'There were no grounds .. I just left them ... It happened to me: as

\footnotetext{
${ }^{56}$ Lawrence, Aaron's Rod, 8.

${ }^{57}$ Lawrence, Aaron's Rod, 145.

${ }^{58}$ Lawrence, Aaron's Rod, 144.

${ }^{59}$ Lawrence, Aaron's Rod, 124.

${ }^{60}$ Lawrence, Aaron's Rod, 127.
} 
birth happened to me once - and death will happen. It was a sort of death too . . But as undeniable as either. And without any more grounds. ${ }^{.161}$

Consequently, he seems to be merely a "criminally selfish" man in "a wicked state of mind" when he is regarded as a man at all, both Lottie and Lady Franks attacking his masculinity, deriding him as "unmanly. "62 The landlady in whose company he has been many a night also calls him "selfish" when he scoffs at the notion that he should take an interest in the welfare of children. ${ }^{63}$ While the charge that he is unmanly is true enough in the sense that he has abandoned a man's responsibilities as they were understood in a culture dominated by the love-urge (responsibilities to family and society), and the charge of selfishness is likewise true in that he is totally self-directed, these charges are also oversimplifications. ${ }^{64}$

While it is possible to regard Lawrence's attacks on the love-urge and his glorification of the power-urge as an elaborate and hypocritical rationalization of caprice, it is clear that this is not the impression that Lawrence had meant to convey to the reader. Aaron, after all, does not live happily ever after as a consequence of abandoning his responsibilities. ${ }^{65}$ By partaking in only one side of life (that of taking and consuming, of

\footnotetext{
${ }^{61}$ Lawrence, Aaron's Rod, 125, 147.

${ }^{62}$ Lawrence, Aaron's Rod, 145.

${ }^{63}$ Lawrence, Aaron's Rod, 21.

${ }^{64}$ Ibid.

${ }^{65}$ In Kangaroo, Lawrence's protaganist would make much of the radical, categorical, even "caste" distinction between the responsible and the irresponsible. Lawrence, Kangaroo, 21-22.
} 
living solely for himself) he ceases to suffer from the bifurcation affecting his society at large as he lives by a single value system rather than two. However, there is more to completeness than going undivided in this superficial sense; wholeness requires the reintegration of the two value systems together, the path to which appears to him to be submission to a "greater soul". Aaron, in other words, desires to serve someone who is greater than himself, who will in turn be responsible for him, rather than a customer, employer or other private individual connected to him solely through the marketplace, or an impersonal "mass" of human beings.

It is this that Lilly must eventually explain to him, something he can do because he had apparently reached the same point much earlier in his life. While the novel begins with Aaron's breaking away from his family and his occupation, which is to say the point in his life where he shifts from one who is consumer and producer to one who is solely a consumer, Lilly has been strictly a consumer long enough to have defined himself as such when the reader first encounters him. He will "'never directly work to earn money... with an eye to the market", not out of inability but out of "contempt for actual work by which a man makes provision for his years and for his family." ${ }^{166}$ Instead he seems "to believe that he has the Invisible - call it Providence if you will - on his side, and that this Invisible will never leave him in the lurch, or let him down, so long as he sticks to his own side of the bargain and never works for his own ends."167

\footnotetext{
${ }^{66}$ Lawrence, Aaron's Rod, 142-143.

${ }^{67}$ Lawrence, Aaron's Rod, 143.
} 
Nevertheless, the question remains as to how to realize the power-urge, much as the love-urge had been realized in the form and substance of the world around them. The reality is that "Lawrence's anti-industrialism . . was a set of emotions and fantasies that never amounted to a serious program except during his association with Bertrand Russell in $1915^{\prime \prime 68}$, Lawrence having been incapable of pragmatic planning, and his ideals better understood as spiritual goals rather than as a party platform, or symbolically rather than realistically. ${ }^{69}$ Lawrence also appears to have been aware of this. As Aaron suggests when he tells Sir William that other people can please themselves, Lawrence is unconcerned with the economic or political viability of such projects. ${ }^{70}$ Even were the creation of a viable project a real desire for Lawrence, such an exercise (undertaken by so many other intellectuals of his day, "like Ford, Belloc, Forster or Gallworthy") appeared futile, his being an essentially tragic age, as he put it at the start of Lady Chatterley's Lover. The only resistance that the countryside could have hoped to offer Second Wave civilization was "its spiritual opposition to industry and the city . . because the rural way of life cannot and will not defend itself against the profound wish of modern man" to extend the machine world. ${ }^{71}$

Moreover, it would appear that the power-urge which wills nothing in particular and opts for "somewhere else" than logic is antithetical to carefully reasoned-out programs.

${ }^{68}$ Delany, 83.

69 Joyce Wexler, "Realism and Modernists' Bad Reputation" Studies in the Novel. Spring 1999: 69 .

${ }^{70}$ Delany, 83 . 
As Lawrence writes, "Don't grumble at me, then, gentle reader, and swear at me that [Aaron] wasn't half clever enough to think all these smart things, and realise all these fine-drawn-out subtleties . . he wasn't. ${ }^{172}$ Instead, he realized them as a musician, whose deepest ideas were not word-ideas ... his very thoughts ... not composed of words and ideal concepts ... they ... . were dark and invisible, as electric vibrations are invisible no matter how many words they may purport . . . If $\mathrm{I}$, as a word-user, must translate his deep conscious vibrations into finite words . . . I do but make a translation of the man. He would speak in music. ${ }^{73}$

In short, he comprehended through the intuition of the artist, rather than the reasoning of the philosopher, and Lilly's understanding and expression of the same concepts appears to be similarly intuitive. (As Lawrence later writes in Kangaroo, "Each formulated religion is in the end only a great idea. Once the idea becomes explicit, it is dead."174) Consequently, Lilly offers no equivalent of President Wilson's "Fourteen Points" for a world where the power-urge reigns, but instead offers a vision of an authoritarian future that can evoke only derision from a Second Wave ideologist, whether capitalist or socialist. Levison, hearing Lilly explain himself, only smiles a "long, slow, subtle smile of ridicule. It all seemed to him the preposterous pretentiousness of a megalomaniac - one whom, after a while, humanity would probably have the satisfaction of putting into prison, or into a lunatic asylum." ${ }^{75}$

${ }^{71}$ Ibid.

${ }^{72}$ Lawrence, Aaron's Rod, 164.

${ }^{73}$ Ibid.

${ }^{74}$ Lawrence, Kangaroo, 263.

${ }^{75}$ Lawrence, Aaron's Rod, 282. 
Lilly's dictatorship is one in which human beings freely submit to a greater soul, making a voluntary gift of themselves to those whom they accept as being in authority over them. In this society, the "idealists and the theorising Jews, and after them your nicely-bred gentlemen, and then perhaps your profiteers and Rothschilds, and all politicians, and ending up with the proletariat" would all be slaves and not masters, and the "professional classes" would be the "sewerage slaves", the lowest of the low. ${ }^{76}$ The changed relationship of the lower to the upper orders, once changed, is to be held fast by "permanent and very efficacious power", including force. ${ }^{77}$

Nonetheless, because Lilly believes that "'every man is a sacred and holy individual, never to be violated", and hates nothing so much as bullying, the volition of those who would become slaves is indispensable to the foundation of such a system, though they can scarcely back out of it. The power wielded is not to be used for mere selfaggrandizement, to allow one individual to annihilate the personality of another human being, or to reduce them to a state of subservience. It is the "heroic soul in a greater man" rather than any mere caprice which is to give others guidance. ${ }^{78}$

Obviously, this attempt to make his thoughts on bringing balance to human life manifest contains inherent contradictions which eventually lead up to his ultimate rejection of "power" and his attempt to strike a new balance in his last work, Lady

\footnotetext{
${ }^{76}$ Lawrence, Aaron's Rod, 279.

${ }^{77}$ Lawrence, Aaron's Rod, 282.

${ }^{78}$ Lawrence, Aaron's Rod, 299.
} 
Chatterley's Lover. ${ }^{79}$ Nevertheless, Lawrence continues to develop these themes in the next two books of his leadership trilogy, and in Kangaroo, seems to be seeking just the kind of leader possessed of a heroic soul that he describes here.

${ }^{79}$ Daleski, $210-211$ 


\section{CHAPTER II: KANGAROO}

Like The Rainbow or Women in Love which preceded it, and with which Lawrence had initially meant to identify it, Aaron's Rod began as an inquiry into the love between men and women, but more clearly than the other two, ended as an inquiry into "the love which would save nations and solve evils ... the love men trust in as a rhythm of the universe. ${ }^{180}$ Kangaroo, however, begins where Aaron's Rod leaves off, exploring the fate of nations and the rhythms of the universe.

While Rawdon Lilly in the earlier book has a vague vision of the sort of society he would like to see come about, he offers no practical thesis or plan of action, and even if he did, he appears to lack the "philosophical interest or physical aura" necessary to be the kind of leader he describes. ${ }^{81}$ In the Australia that Lawrence depicts in Kangaroo, however, there are two rival factions struggling for power, one protofascist (the Diggers) and one socialist (the Magpies), each led by a would-be ruler, Ben Cooley (nicknamed Kangaroo) and Willie Struthers, respectively. While it would seem a foregone conclusion that Lawrence's protagonist Richard Somers would inevitably reject the socialism of Willie Struthers, Lawrence nonetheless allows Somers to be tempted by his ideology as well. Struthers's socialism, after all, offers more than what Lawrence derided as the

80 "Kangaroo" Ed. R. P. Draper, D.H. Lowrence: The Critical Heritage (London: Routledge \& Kegan Paul Ltd., 1970) 215.

${ }^{81}$ Niven, 137. 
"profiteering" of the work-man; it promises a fellowship between men of the kind that Somers, or at least a part of Somers, had long craved but never been able to find.

Nevertheless, both leaders, and the belief systems that they have to offer, are found wanting because while those systems appear to be opposites, that is only the case within the Second Wave framework that Lawrence had clearly rejected. That fact, and its implicit limitations, is also why Lawrence must reject not only Ben Cooley, but Australia. All that Lawrence found unappealing in Europe not only appeared in Australia, but seemed to be all the more pronounced there. The white Australians, after all, were transplanted Europeans who came to the continent only at the end of the eighteenth century, by which time democracy and industrialism were already reshaping the Europe they left behind. The Old World, however, had its cultural heritage, "Florence, with Giotto's pale tower: or the Pincio at Rome ${ }^{182}$ to offer resistance to that tidal wave of change, whereas the "massifying" Second Wave met with no opposition in Australia ${ }^{83}$. The result was that Richard Somers felt himself to be surrounded by "uncouth" Second Wave "barbarians" next to whom the "most loutish Neopolitan loafer was nearer" in pulse ${ }^{84}$, in a soulless place of democratic vulgarity where authority was totally absent ${ }^{85}$, Lawrence's definition of a $\mathrm{mob}^{86}$.

${ }^{82}$ Lawrence, Kangaroo, 19-20.

${ }^{83}$ Pinkney, D.H. Lawrence and modernism $1^{\text {st }}$ ed. (Iowa City: U of Iowa P, 1990) 113.

${ }^{84}$ Lawrence, Kangaroo, 20-22.

${ }^{85}$ Pinkney, 113.

${ }^{86}$ Lawrence, Kangaroo, 300. 
The result is that Lawrence evinces "distaste, mockery and anger" at Australia's human face ${ }^{87}$ Before meeting either Ben Cooley or Willie Struthers, Somers muses that the only "living relationship" he could know is one founded on authority, or as he puts it, "the mystery of lordship. The mystery of innate, natural, sacred priority . . the joy of obedience and the sacred responsibility of authority" which "democracy and equality", which has "almost triumphed" (all Second Wave governments being democratic or pretending to be), "try to deny and obliterate."

Even if Ben Cooley's lieutenant Jack Callcott blames Australia's "fermenting rotten" state on democracy and looks to discipline and obedience to "wisdom and authority" to save the country, he is still thinking in terms of mass politics. As democratic or pseudodemocratic mass ideologies justifying themselves through reference to "the good of the people", each leader's political ideology, the paternalism of Cooley and the fraternal idealism of Struthers, is also founded on the love-urge (the producer, rather than the consumer side of the individual in Tofflerian terms) that Richard has come to regard as exhausted. Moreover, neither Ben Cooley nor Willie Struthers can be convinced to present an alternative to this trend by founding their politics on the "somewhere else" other than Second Wave logic to which Lilly refers near the end of Aaron's Rod.

Jack Callcott's politics, the brand of fascism that makes the trains run on time, is necessarily the politics of a machine civilization. The organization, which consists of veterans of the First World War, prides itself on its members' understanding of the importance of command and obedience, not the mysterious sort which fascinates Somers,

\footnotetext{
${ }^{87}$ Niven, 145.
} 
but the kind that they learned in the military, nothing else being "the slights bit good." ${ }^{88}$ The army, which took industrial-style rationality to perhaps its greatest extreme, is their model not only for the Diggers' clubs, but also for the civil world of the new Australia they wish to create. Their emphasis on service and on sacrifice, the notion that Somers, had he been an Australian, would have been obliged to "do something about" the danger posed by Australia's more populous and "unfree" Asian neighbors who will "squash [Australia] like a soft pear" if given the chance reflects the love-urge, and the secularism and nationalism of Jack's outlook are also Second Wave characteristics. ${ }^{89}$ The Diggers also show their Second Wave origins and concept through their emphasis on urban areas, Jack's first thought of the strength of his organization being their presence in Sydney. ${ }^{90}$

What Somers finds when he actually meets Ben Cooley, or Kangaroo as he is also known, his first impression is not of a stern authoritarian who will transform Australia into a great war machine, but of a man who wishes to someday be a "quiet, gentle father" to his country. ${ }^{91}$ When Kangaroo

smiled ... there came an exceedingly sweet charm into his face, for a moment his face was like a flower ... he was almost purely kind, essential kindliness . . . for any human being who showed himself sincere and vulnerable, his heart was pure in kindness ... This pure kindliness had something Jehovah-like in it . . It had given his soul an absolute direction. ${ }^{92}$

${ }^{88}$ Lawrence, Kangaroo, 89.

${ }^{89}$ Lawrence, Kangaroo, 89-93.

${ }^{90}$ Lawrence, Kangaroo, 92.

${ }^{91}$ Mbid.

${ }^{92}$ Lawrence, Kangaroo, 110-111. 
Such "Jehovah-like" kindness is necessarily identified with the love-urge, which he makes clear is the foundation of his belief system. Kangaroo defines good as the recognition of life's urges as they arise (or at least the attempt to do so), and evil as "antilife", or in other words, the "Malignant resistance to the life principle." ${ }^{193}$ Nevertheless, Kangaroo makes it clear that there is no place for such "malignant resistance" in his vision of the world, and that his belief is in the one fire of love, which he takes to be synonymous with life, the flames of "life and love" inside man's heart being one. ${ }^{94}$ "I believe" Kangaroo tells Somers, that love "is the inspiration of all creative activity. I trust myself entirely to the fire of love ... There is no other" force. ${ }^{95}$

Kangaroo's political program is the realization of that love-urge. While "there must be law, and there must be authority", that law must have humanity and wisdom. ${ }^{96}$ While Kangaroo tells Richard that while he has ". . the greatest admiration for the Roman Catholic Church, as an institution ... we need something more flexible, and a power less formal and dogmatic; more generous, shall I say." ${ }^{197}$ Rather than a king or a president, Kangaroo sees himself as a pope or a patriarch, representing as "near as possible the wise, subtle spirit of life", and unlike any infallible pope, his "benevolent tyrant" will be

${ }^{93}$ Lawrence, Kangaroo, 112-114.

${ }^{94}$ Lawrence, Kangaroo, 134.

${ }^{95}$ Lawrence, Kangaroo, 133.

${ }^{96}$ Lawrence, Kangaroo, 112.

${ }^{97}$ Tbid. 
circumscribed by a constitution - the head of a benevolent, constitutional "Church of Australia."

Regardless of what terminology is used to describe the political system that Kangaroo hopes to someday establish in Australia, it is undeniably "other-directed" and "lovedriven", and almost immediately this fact inspires misgivings in Richard Somers. Where Aaron in Aaron's Rod is intuiting the death of the love-urge and only becomes fully aware of it at the end of the novel, its story being a joumey of discovery for Aaron, the death of the love-urge is already a premise for Somers, who feels that "he had come to the end of transports: they had no more mystery for him; at least this kind: or perhaps no more charm. Some bubble or other had burst in his heart."198 Where Kangaroo feels love "as plain as toothache", love "has become like cardboard" to Somers. ${ }^{99}$

While Kangaroo does not completely lose his fascination for or hold on Somers (something that would persist until Kangaroo's death), Somers's attempt to explain his own position to Kangaroo foreshadowed Somers's eventual refusal to embrace Kangaroo's ideology. "I know your love, Kangaroo," Somers told him,

"Working everything from the spirit, from the head ... You work the lower self as an instrument of the spirit . . . it is time for the spirit to leave us again; it is time for the Son of Man to depart, and leave us ... in front of the unspoken god: There is a great god on the threshold of my lower self." 100

Kangaroo's reply is a "weary, impatient, condescending sigh ... 'I was never able to follow mysticism and metaphysics. One of my many limitations. I don't know what you

\footnotetext{
${ }^{98}$ Lawrence, Kangaroo, 132-133.

${ }^{99}$ Tbid.
} 
mean."' ${ }^{101}$ For all his protestation that metaphysical questions are beyond him, the reality is that the practical Kangaroo is not uninterested in them. Somers correctly points out that Kangaroo's conception of love is necessarily a mystical thing, and his feel for the mystical must be exceedingly strong if it is something that he can feel as a toothache. However, Kangaroo believes that love is the answer to all of the spiritual questions that matter, and the exhaustion of the love-urge and the need to turn to the power-urge for renewal which obsess Richard Somers do not exist for Ben Cooley, who merely seeks to express love through service, something that people have not been properly able to do. In his view, "man has not yet begun" to explore love, and even as he lay dying of gunshot wounds incurred in a battle between his party and the socialists, Kangaroo tells Richard (even as Richard finds himself unable to tell a dying man that he loves him) that the problem is not the sickness of the love-urge, but rather its never having been properly known:
"They have never known the full beauty of love, the working classes. They have never admitted it. Work, bread has always stood first. But we can take away that obstacle. Teach them the beauty of love between men, Richard, teach them the highest. . how to love their own mate, and you will solve the problem of work forever. ${ }^{102}$

With the great question solved, Kangaroo can afford to be essentially worldly in his interests, if not so hard-headedly materialist as the "money-grubbing socialists" Lawrence so disdains. His definition of the generous power of the Australian Church that he envisions is that of an institution which "sees all the issue here, not in the after-life, and

\footnotetext{
${ }^{100}$ Lawrence, Kangaroo, 135.

${ }^{101}$ Ibid.
} 
that does not concern itself with sin and redemption... The salvation of souls seems too speculative a job." ${ }^{103}$ The benevolent tyranny that Kangaroo means to establish is to "remove physical misery as far as possible", and consistent with his belief in the primacy of love and service as an expression of love, to accomplish this by requiring "a certain amount of state labour" on the part of the husbands in "public kitchens where the children can get properly fed", thus enabling the people to lead "full, substantial lives." 104 Otherwise, they go their own way, seeing to their "minds, their souls, their spirits" as they see fit. ${ }^{105}$

The result of the great question's having already been resolved for Kangaroo, and his shift away from metaphysical speculation to the realization of the truths he believes that he has already learned, is an unbridgeable gap between the two men. Just as Somers can not share Kangaroo's love-urge, Kangaroo does not understand the power-urge about which Somers speaks, a force he does not believe exists in his universe, so that Kangaroo imagines that Somers has a. "demon" inside him that makes him perverse and must be exorcised for his own good. ${ }^{106}$

Ironically Kangaroo, who declared that there was nothing but love, fits his own definition of evil as anti-life in Somers's view, resisting as he does the only life urge that matters to Somers, the power-urge, so that despite Kangaroo's sense that Somers is

${ }^{102}$ Lawrence, Kangaroo, 325.

${ }^{103}$ Lawrence, Kangaroo, 112.

${ }^{104}$ Lawrence, Kangaroo, 111-112.

${ }^{105}$ Ibid. 
possessed by a figurative demon, it is Kangaroo's belief in love which appears "devilish" to Somers. The use of the term "devilish" here is critical, particularly since Somers had already identified Kangaroo with the Judeo-Christian tradition and the exhausted urges which it represents.

The dark gods which Somers seeks, the "new Christ" so to speak, are the antithesis of Ben Cooley and Jehovah, making them the anti-Christ to his new Christ, Kangaroo's belief in love a creed to be rejected and his god a false god which will in time be overthrown by the new, living god. At the same time, Kangaroo's characterization of Somers as possessed by a demon has credence, because that is how the dark gods must always appear to the "white gods" 107 , frightening however liberating they may actually be. The relationship between the two urges and principles is perhaps best illustrated by Lawrence's inversion of Biblical commands:

Blessed are the pure of heart . . because the pure in heart are those who quiver to the dark God . . . Ramses II was no doubt as pure in heart as John the Evangel. Indeed perhaps purer ... To be pure in heart, man must listen to the . . call to the blood-sacrifice as well as to the eucharist...

Blessed are they that do hunger and thirst after righteousness. . . but the righteousness of the profound listener ... Not any other righteousness, of the commandment sort. ${ }^{108}$

The devilishness of Christianity is therefore relative, as Lawrence writes life "always" 109 is, its value (or lack thereof) being determined solely by the urges and needs of the

${ }^{106}$ Lawrence, Kangaroo, 136.

${ }^{107}$ Lawrence, Kangaroo, 268.

${ }^{108}$ Lawrence, Kangaroo, 267-268.

${ }^{109}$ Lawrence, Kangaroo, 267. 
moment rather than a generalized hostility to religions of love, mind and spirit per se (a point he explores more thoroughly in The Plumed Serpent).

Willie Struthers, the socialist, may conspicuously lack the seemingly infinite kindness of a Kangaroo, or the "sweetness that one can find in Abraham Lincoln's portraits", but Struthers is as much a creature of the love-urge as Ben Cooley. ${ }^{110}$ If anything, "this last leaf of communism" was the last "logical leaf" that "the lily-tree of humanity rooted in love" had to put forth before it "died its final death." 111 To achieve his own version of a better society, Struthers may wish to knock down the sacred cows of "the Great Washed and their medicine men", but he insists that "you've got to build up as you knock down." What Struthers intends to build up is a "new bond between fellow-men"

... this love, this mate-trust called into consciousness and highest honour. $\mathrm{He}$ wanted to set it where Whitman tried to set his Love of Comrades. It was to be the new tie between men ... the new passional bond in the new society. The trusting love of a man for his mate. ${ }^{112}$

Once again, Somers sees the would-be leader starting from the exhausted premise of love, and again a gap appears between him and the man he may have wished to follow. While, as happened with Kangaroo, he is initially moved by Struthers's enthusiasm for "the working-people", Richard can not help but be disappointed at the "limited, secular nature of the enterprise", and argues that there must be a religious aspect to this new society. ${ }^{113}$ In reply, Struthers tells him that "all the Churches are established on Christ.

\footnotetext{
${ }^{110}$ Lawrence, Kangaroo, 193.

${ }^{111}$ Lawrence, Kangaroo, 265.

${ }^{112}$ Lawrence, Kangaroo, 197.
} 
And Christ says Love one another -", a statement that evokes laughter from Richard. ${ }^{114}$ Christ, as Lawrence would write again in The Plumed Serpent, was in his eyes an exhausted divinity, and only the "first, dark, Unnamed God whom men had once known so tremendous" 115 offered a rock on which to build now, but a man like Struthers had no use for deities from outside the love-driven Judeo-Christian tradition. ${ }^{116}$

Just as love failed on the individual and personal level in Aaron's Rod, the marriage of Aaron to Lottie in Aaron's Rod being destructive of both of them and ending in hatefulness between husband and wife, love also seems destined to fail on the political level in Kangaroo, politics founded on the love-urge bringing only death and destruction, the "collapse of the love-ideal" bringing on "chaos and anarchy . . in the name of love and equality. "117 Again, Lawrence believes this lesson to be borne out by history:

When a man follows the true inspiration of a new, living idea, he then is the willing man whom the Fates lead onwards: like St. Paul or Pope Hildebrand or Martin Luther or Cromwell or Abraham Lincoln. But when the idea is really dead, and still persists in following it, then he is the unwilling man whom the Fates destroy, like Kaiser Wilhelm or President Wilson ... ${ }^{118}$

In the distinction between an Abraham Lincoln and a President Wilson lies Lawrence's philosophy of history. It is a perpetual shift from one balance to another, not a progressive teleological movement, but the "perpetual call and answer" that is the human

${ }^{113}$ Wright, D.H. Lawrence and the Bible (Cambridge: Cambridge UP, 2000) 146.

${ }^{114}$ Lawrence, Kangaroo, 201.

${ }^{115}$ Lawrence, Kongaroo, 202.

${ }^{116}$ Wright, 145.

${ }^{117}$ Lawrence, Kangaroo, 328. 
soul. What made a Cromwell or a Lincoln great, and destroyed a Wilhelm or a Wilson, was that they went with the flow of their time, rather than against it. Consequently, the true cruelty of the Great War was not in the mechanized horrors of the Western Front or the bullies who abused their authority at home (with whom Lawrence had had his brushes, inspiring the lengthy recollection of Richard Somers's wartime experience), but its movement in the opposite direction to this flow.

Implicit in such a resistance to the urges of the individual and the imperatives of History is a stab in the back which is what made this war above all the others in which modern man had been involved so unbearable that "men will not forgive the war, and their humiliation at the hands of these war-like authorities." 119 That stab in the back was in the infliction of all this suffering on human beings in the name of the ideals of "Love, Self-Sacrifice, Humanity united in love, in brotherhood, in peace" which made even conscientious objection to the war a hypocritical admission of the dead ideal. ${ }^{120}$ "The conscription, all the whole performance of the war was absolutely circumstantially necessary ... Even Richard, even now, agreed fully to all these contentions", but, Lawrence goes on to write, in his "instinctive, passional self" with which there could be no argument, he felt "desecrated" and "sold." ${ }^{121}$ All that is left when human beings reach such a point, Somers believes, is revenge.

${ }^{118}$ Lawrence, Kangaroo, 263.

${ }^{119}$ Ibid.

${ }^{120}$ Lawrence, Kangaroo, 264.

${ }^{121}$ Lawrence, Kangaroo, 262. 
The moment a man feels he has been sold ... something goes wrong with his deepest mechanism ... And then, he . . becomes a creature of . . Revenge on all that the old ideal is and stands for. Revenge on the whole system ... when they felt sold. ${ }^{122}$

It has happened before, and Somers was certain that it would happen again. "Men revenged themselves on Athens, when they felt sold. When Rome, persisting in an old, defunct ideal, gradually made her subjects feel sold, they were revenged on her, no matter how. Constantinople and the Byzantine Empire the same." ${ }^{123}$ The title of the chapter, "Revenge, Timotheus cries" was an allusion to an instance of such revenge, the revenge that Timotheus called for in the wake of another war for a dead ideal, Alexander the Great's conquest of Persia. ${ }^{124}$

Today, everyone was Timotheus, or soon would be, excepting those who have money and power, which Lawrence sees as being the same in his time, the "only real master left [being] the boss in industry." ${ }^{125}$ However, he uses the term "industry" loosely, elsewhere referring to the wielders of money and power as those who had "got into business and [were] successfully coining money. That seemed to be the only safety-valve: success in money-coining." 126 The way in which Lawrence describes the successful "moneycoiners" is notable in that he does not refer to the work which creates wealth, but rather the purely acquisitive aspect of economic life, rather than production or service.

\footnotetext{
${ }^{122}$ Lawrence, Kangaroo, 264.

${ }^{123}$ Ibid.

${ }^{124}$ Lawrence, Kangaroo, 260.

${ }^{125}$ Lawrence, Kangaroo, 303 ,
} 
Willie Struthers, who correctly observes that Somers is "no believer in Capitalism", misunderstands the real reasons for that disbelief, and mistakes these opinions for leftist leanings. Lawrence is unconcerned with capitalism's exploitative aspect, so that Somers is unmoved by Struthers's assertion that under capitalism "for every one that gets on, you must have five hundred fresh slavers and toilers to produce the graft." ${ }^{127}$ However, nor does Lawrence refer to conventional defenses of capitalism, such as demonstrating that the capitalist deserves his gains because it is he who assumes the risk. Right and wrong, good and bad, fair and unfair in any conventional sense have nothing to do with it in his view, only the gratification of claiming and possessing, and Somers believes that the members of political movements which are ostensibly hostile to capital have at bottom the same desire as the capitalist. The Diggers, for instance, are unable to "hate the capitalist with a self-righteous hate [because] ... They know that if they themselves got a chance to make a pile of money and be capitalists, they'd jump at it . . The most that they'll do is sneer about him." ${ }^{128}$

Again, as in the first chapter of Aaron's Rod, consumption is the sole means by which industrial society permits the power-urge to be expressed, however crudely. Even were that not the case, he realizes that this safety-valve is not going to make much difference at the level of whole societies. "How many men were successful, now?" Richard wonders, and whatever the answer is, the number of them can never be enough to make a difference. Save for the fortunate few who were coining money, all that humanity had

${ }^{126}$ Lawrence, Kangaroo, 197.

${ }^{127}$ Lawrence, Kangaroo, 260. 
was its hatred, and it was neither feasible nor desirable that the masses be placated through a redistribution of wealth.

Just as the proponents of the Rural Myth in the nineteenth and twentieth centuries did not wish to see socialism come about in order to allow the lower orders to consume more, Lawrence does not see anything sacred in the getting of material goods, or anything particularly exceptional about those who succeed at the game. Moreover, he finds a "dictatorship of money" as objectionable as a "dictatorship of the proletariat", if not more so:, "for this superiority based on possession of money is worse than any of the pretensions of Labour or Bolshevism, strictly. "129 At least allowing the socialists to finish capitalism through the establishment of communal ownership would bring on the end of the Labour movement, and the great Second Wave struggle over the market concluded, the civilizational "super-struggle" for a truly new way of life could begin. "Let the serpent" of Labour swallow itself, he writes, for "Then we could have a new snake", and start to at least seek out a "new show ... a departure from the dreariness of moneymaking, money-having, and money-spending" and a "new recognition of the lifemystery." 130

In the meantime, still trapped within an industrial civilization and charged with his desire to exact vengeance, Richard felt himself to have already been pushed beyond the point of no return, and moreover, that his condition was a universal one rather than something particular to him. He was "full of a lava fire of rage and hate, at the bottom of

${ }^{128}$ Lawrence, Kangaroo, 195.

${ }^{129}$ Lawrence, Kangaroo, 303. 
his soul . . He cared for nothing now, but to let loose the hell-rage that was in him ... For there was no digesting it. ${ }^{131}$ He also realized that "the Russians must have reached it during the war: that the Irish had got there: that the Indians in India were approaching the point: that the whole world was gradually working up to the pitch." ${ }^{132}$

The same went for both Ben Cooley and Willie Struthers, each of whom had been betrayed by the dead ideals and now sought to take their revenge with the instruments they had at hand, even if those were outwardly the dead ideals themselves. The love they spoke of was synonymous with the hatred they felt, that hate merely the recoiling of love, as Lilly put it to Aaron in Aaron's Rod. While "Kangaroo insisted on the old idea as hard as ever" what he really wanted was to "take his revenge in an odour of sanctification and Lily of the Valley essence ... he was the mob, really . . the vengeful mob." ${ }^{133}$ Willie Struthers was no different, the "vengeful mob also." ${ }^{134}$ Such suspicions, hinted at it in the gap between the rhetoric of Ben Cooley and Jack Callcott, and Jack's suspicion that Richard is a spy (which leaves him "aghast" at Jack's malevolence) ${ }^{135}$, are for him proven beyond the shadow of a doubt in the melee which kills Kangaroo. That melee also kills

${ }^{130}$ Tbid.

${ }^{131}$ Lawrence, Kangaroo, 261.

${ }^{132}$ Lawrence, Kangaroo, 261-262.

${ }^{133}$ Lawrence, Kangaroo, 265.

${ }^{134}$ Ibid.

${ }^{135}$ Lawrence, Kangaroo, 291. 
the gentle benevolence of Kangaroo's vision ${ }^{136}$, and lays bare Jack's bloodlust, which Richard regards as representative of the whole Digger movement:

"Cripes, there's nothing bucks you up like killing a man- nothing ... Having a woman's something, isn't it? But it's a flea-bite, nothing, compared to killing a man when your blood comes up. Bah - having a dozen women all at once wouldn't compare with it." 137

Richard Somers's experiences with the great mass movements of his time, invariably acting on the hatred that sprang from a recoiling, betrayed love-urge, leave him disappointed. In politics, his problem is not one of bewildering overchoice but of "so little to choose" from, since the two parties of which he had just had experience were offering the correct answer to the wrong question, asked within the too-small framework afforded by industrialized society:

Kangaroo and Struthers were both right ... Lords or doctors or Jewish financiers should not have more money than a simple working man, just because they were Lords and doctors and financiers. If service was the all in all, it was absolutely wrong. ${ }^{138}$

The point was that love and service were not the "all in all". Just as Aaron Sisson was unsatisfied leading an unbalanced life, one which was totally self-centered and therefore incomplete, the politics of the love-urge are no more because they deny the power-urge (and with it, the producer-consumer split), something Kangaroo does explicitly when he denies that there is any force but love. If anything, their preoccupation with love makes them even poorer because they have opted for the side of human life which is already

136 Paul Poplawski, Promptings of Desire (Westport, Connecticut: Greenwood Press, 1993) 150.

${ }^{137}$ Lawrence, Kangaroo, 319. 
overstressed and running counter to the counterbalancing urges being awakened by the dark gods.

As a result, the only real role that Kangaroo and Struthers could seriously hope to play in history was a negative one, the destruction of the old rather than the creation of something new and vital. Despite Callcott's talk of his blood coming up, mob violence, like the violence of the First World War, is a "sort of terrible automatism, which has no true connection with the vertebral consciousness", gathering its force instead from tired "mental expression." ${ }^{139}$ In spite of themselves, the socialists and fascists would in their hatred sweep away the industrial civilization that Somers hates and permit a new society to grow up in its place, so that he is almost looking forward to "chaos and anarchy" 140 , even if, especially after the bloodshed of the melee, he "can't be on other side." 141 Nevertheless, this new society needs a champion, and Somers feels capable of supporting such a champion only. His failure to find such a champion leaves him feeling that he alone recognizes the direction in which life is flowing, unlike the rest of humanity which refuses to put off the "conscious conceit" and listen to their own soul. That realization only affirms his belief that he must get clear of the rest of humanity and look down to the power-urge within himself for restoration:

That was now all he wanted: to get clear. Not to save humanity or to help humanity or to have anything to do with humanity... To be clear of humanity

\footnotetext{
${ }^{138}$ Lawrence, Kangaroo, 327.

${ }^{139}$ Lawrence, Kangaroo, 300-301.

${ }^{140}$ Kermode, 110.

${ }^{141}$ Lawrence, Kangaroo, 316.
} 
altogether ... of love, and pity, and hate ... To turn to the old dark gods, who had waited so long in the outer dark. ${ }^{142}$

Nonetheless, Lawrence is ambivalent about the Second Wave individualism implied in his wish to cut himself off and seek his own, personal salvation, such "ultra-freedom" being incompatible with wholeness. The "capacity to question, to doubt, to rebel, to sin" is in his view a "burden that the mass of humanity can not support."144

Aaron Sisson in Aaron's Rod leaves home to venture to London and later Italy. Nevertheless, Aaron is not leaving behind his church, his lord or his extended family, but his union, his employer and his "streamlined" nuclear family, all of which are Second Wave institutions themselves composed of atomized individuals in any case. Moreover, Aaron is by no means complete, however much he may fancy himself as self-contained, and he eventually finds himself searching for a greater soul to which to submit, to make himself whole through obedience to a master.

${ }^{142}$ Lawrence, Kangaroo, 265.

${ }^{143}$ Alvin Toffler makes the argument that the Second Wave view of matter, both the matter of which the universe was made and the matter in human machinery like states and corporations, was of human beings as "discrete, indestructible, irreducible, invisible, unsplittable" particles, in a word, atoms. Rather than being a "passive appendage of tribe, caste or clan", or links in a greater chain of being inside the cosmos, human beings were free and autonomous. That autonomy allowed them to be torn loose from the "extended family, the all-powerful church, the monarchy" - the social structures of First Wave civilization - and reassembled as the institutions of Second Wave civilization (its mass armies, factories and bureaucracies) required. Toffler, The Third Wave, 109-112.

${ }^{144}$ Phillip Sicker, "Lawrence's Auto da fe: The Grand Inquisitor in The Plumed Serpent" Comparative Literature Studies 1992: 426. 
In Kangaroo, Richard Somers is insistent on the importance of man's being alone with his soul. ${ }^{145}$ "Man's isolation was always a supreme truth and fact, not to be forsworn" 146 and the mass of humanity evokes his contempt: "It is a world of slaves: all loveprofessing. Why unite with them? Why pander to them? Why go with them at all?"147 Humanity, Richard believes, has to learn that "It is the individual alone who can save humanity alive." ${ }^{148}$ Yet, that individual who is going to save humanity single-handedly "must have deep, throbbing roots down in the dark red soil of the living flesh of humanity." 149 Even those who would not be culture heroes also "cannot live a life of entire loneliness ... There's got to be a meeting: even communion." ${ }^{150}$ The individual certainly can not be free of the sacred, since to absolve oneself of the Lord was also to fall prey to devils ${ }^{151}$, and he finds himself pining for the mental oneness experienced by the "hot-blooded whales"152.

In this observation, Somers all but lays out just how he intends to meet with his fellow human beings, by descending into the "darkness" that is nature, essentially reestablishing

\footnotetext{
${ }^{145}$ Lawrence, Kangaroo, 281.

${ }^{146}$ Lawrence, Kangaroo, 327.

${ }^{147}$ Lawrence, Kangaroo, 138.

${ }^{148}$ Lawrence, Kangaroo, 302.

${ }^{149}$ Ibid.

${ }^{150}$ Lawrence, Kangaroo, 351.

${ }^{151}$ Lawrence, Kangaroo, 283.

${ }^{152}$ Lawrence, Kangaroo, 301.
} 
the connection with the land that industrialized civilization with its concentration of men in modern cities has destroyed. It is with mankind, not with nature, that Lawrence feels he must fight ${ }^{153}$, and so it is nature which will afford the opportunity for human beings to reconnect with one another so that they neither sacrifice their individuality, nor live in a loneliness that man was never intended to suffer. Australia, with its narrow sliver of civilization along the coastline and its "immense, uncharted, dark interior" is an almost perfect objective correlative for the inner and outer worlds that Lawrence wishes to investigate. $^{154}$

Australia is "the land that as yet has made no great mistake, humanly. The horrible human mistake of Europe. And probably, the even worse human mistake of America." 155 People here mattered so little against the vast and untamed Bush, man all but unnoticeable in its silences ${ }^{156}$, the loneliness of the bush where he believes the dark god must live ${ }^{157}$. However much he may dislike the people who live in Australia, he never loses his "sense of marvel at the physical grandeur" of the place ${ }^{158}$, so that Richard can

${ }^{153}$ Wright, 146.

154 John B. Humma, "Of Bits, Beasts and Bush: The Interior Wilderness in D. $H$. Lawrence's Kangaroo" South Atlantic Review Jan. 1986: 87.

${ }^{155}$ Lawrence, Kangaroo, 347.

${ }^{156}$ Lawrence, Kangaroo, 345-347.

${ }^{157}$ Niven, 145.

${ }^{158}$ Niven, 146 . 
say in the final chapter, "I don't love people . . But this place - it goes into my marrow, and makes me feel drunk. I love Australia." 159

Nonetheless, Richard is leaving Australia, proceeding to America. While the place is a source of dread to him, the Americas, and specifically Mexico, will be the scene where the quest for a new way of living concludes, both in its capping off the trilogy, and in its presenting a leader who literally looks back to the dark gods of the past for the rejuvenation of the present.

${ }^{159}$ Lawrence, Kangaroo, 347. 
CHAPTER III: THE PLUMED SERPENT

While (or perhaps because) The Plumed Serpent is the most maligned of Lawrence's, it represents the fullest development of his "power" theme. In Tofflerian terms, where Aaron's Rod explored the cleft personality created by a market-centered world (and particularly the suppressed consumer-power urge), and Kangaroo concerned the failure of any Second Wave political ideology to repair the cleft (the disappointment of Richard Somers in fascism and socialism, these being creeds of love), The Plumed Serpent looked to the forsaking of machine civilization for a pre-industrial way of life where the powerurge reigns, bringing about balance and wholeness. Rather than dealing with the failure of love, as he had done in so many earlier works, Lawrence depicted the triumph of power.

From the start, Lawrence's character Don Ramon, who would lead the revival of the cult of Quetzalcoat in Mexico, comes down hard in opposition to politics of the European variety, the politics that Lawrence had decisively rejected in Kangaroo. Where it had been possible for Willie Struthers to mistake Richard Somers's dislike of capitalism as a socialist leaning, Don Ramon eliminates any such possibility near the outset: "Bolshevism is one sort of bullying, capitalism another," he declares. ${ }^{160}$ Moreover, he rejects the premise on which they are both founded, and their principal promise, which is human freedom:

${ }^{160}$ Lawrence, The Plumed Serpent, 68 . 
"There is no such thing as liberty. The freest people are slaves to convention and public opinion, and more still, slaves to the industrial machine . . You only change one sort of domination for another. All we can do is to choose our master." ${ }^{\prime 61}$

Moreover, he has a clear idea as to which master he would have: "If I must serve," Don Ramon says, then "I will not serve an idea, which cracks and leaks like an old wineskin . . There is no liberty for a man, apart from the God of his manhood." ${ }^{162}$ In other words, unlike Aaron Sisson who had abandoned service, Don Ramon has found something which he is willing to serve, service, in other words, that will satisfy him, thus recombining production and consumption, and resulting in an integrated personality. ${ }^{163}$ (In Tofflerian terms, he has become a "prosumer", someone who produces for his own consumption, bypassing the marketplace and closing the crucial Second Wave split. ${ }^{164}$ )

Furthermore, that which he is willing to serve is not an idea, something that would come from the head and the spirit, as Richard Somers put it in Kangaroo, and it is clearly not the "industrial machine" which had split apart production and consumption in the first place, but rather his own spirituality. In the service of that idea, Don Ramon believes that he will be able to make other Mexicans whole people like himself, the rest of his people still being bifurcated:

${ }^{161}$ Lawrence, The Plumed Serpent, 67.

${ }^{162}$ Lawrence, The Plumed Serpent, 68.

${ }^{163}$ Vickery, 126.

164 Alvin Toffler's prosumer, notably, belongs to post-industrial, or Third Wave civilization - likewise outside of Second Wave civilization, but defined essentially in economic rather than spiritual terms, and made possible only by further technological 
"Men are not yet men in full, and women are not yet women. They are all half and half, incoherent, part horrible, part pathetic, part good creatures. Half arrived ... And so, having got hold of some kind of clue to my own whole manhood, it is part of me now to try with them."

The result is that Don Ramon can not lead a political movement like Ben Cooley and Willie Struthers did in Kangaroo (and does not pretend to), but instead heads a religious revival, next to which Ramon sees as irrelevant, the questions of the day-to-day world that had for so long been the focus of reform. ${ }^{166}$ Speaking of Mexico's President Montes, who has stated that his goal is to save his country from "poverty and unenlightenment" 167 , Don Ramon says,

"Politics, and all this social religion that Montes has got is like washing the outside of the egg, to make it look clean ... I want to get inside the egg . . to start it growing into a new bird... it is a good egg . . Only the spark of fire has never gone into the middle of it, to start it - Montes wants to clean the nest and wash the egg. But meanwhile the egg will go cold and die. The more you save these people from poverty and ignorance, the quicker they will die: like a dirty egg that you take from the hen eagle to wash it . . let us hatch the chick before we start cleaning up the nest." 168

If anything, Don Ramon views the socialism of President Montes, characterizing it as the "white Anti-Christ of Charity" with "real poison in the communion cup."169 Moreover, it is to stop socialism and reform - so "surcharged... with hate - the hate of

advance, rather than by a retreat from technology into an agrarian past. Toffler, The Third Wave, 265-288.

${ }^{165}$ Lawrence, The Plumed Serpent, 207.

${ }^{166}$ Barbara Mensch, D.H. Lawrence and the Authoritarian Personality (New York: St. Martin's Press, 1991) 248-249.

${ }^{167}$ Lawrence, The Plumed Serpent, 187.

${ }^{168}$ Lawrence, The Plumed Serpent, 188. 
the materialist have-nots for the materialist haves", that he has stepped out of his "ordinary privacy and individuality." ${ }^{170}$ Likewise, Ramon rejects the "conventional" fascism of the Knights of Cortes, who eventually number among Don Ramon's opponents as well. ${ }^{171}$

The religious revival that Don Ramon wishes to lead, moreover, is not Christian but pagan in character, a cult of the pre-Christian Aztec god Quetzalcoatl. ${ }^{172}$ While scholars emphasizing the racial and colonial aspects of The Plumed Serpent have made much of the fact that the Christian God is a foreign god to the people of Mexico, Christ has in a sense become a god foreign to the whole world. Don Ramon rejects Christ not because he is an imposition by "the white people from across the sea", or because Christ is in some other respect inherently unworthy. "God," Dona Carlota quotes Ramon as having said,

"is always God. But man loses his connection with God. And then he can never recover it again, unless some new Saviour comes to give him his new connection. And every connection is different from the last ... the people have lost God. And the Saviour cannot lead them to Him any more. There must be a new Saviour with a new vision." 173

In other words, where Christ had formerly represented the life-urge, that is no longer the case, and it is time for him to retire and allow Quetzalcoatl to come forth. Christ, after all, was a god of the love-urge, and to submit to Christ, as Dona Carlota wishes Ramon to do, is to "submit to love", but that is no longer possible. For Don Ramon, the living god

${ }^{169}$ Lawrence, The Plumed Serpent, 206.

${ }^{170}$ Ibid.

${ }^{171}$ Mensch, 209

${ }^{172}$ Vickery, 124. 
was no longer a god of the head and spirit, but rather a god of the lower reaches and the darkness.

Universal gods of the spirit no longer suffice, the need now being for particularist gods who reflect a reestablished link between a people and the land on which they livelike the dark god whom Richard Somers sensed in the silences of the Australian Bush. As a god of the land, it is notable that Quetzalcoatl appears not in "degenerate" Mexico City (a shabbier version of the concrete-and-steel cities that have proliferated across the industrialized world), but in the countryside, the scene of spiritual resistance to the city and the homogenizing effect of industrialism that had so distressed Aaron Sisson. The countryside is also the scene of all the later action in the novel, when the revolution breaks out and takes the status of the cult of Quetzalcoatl up from eccentricity to state religion. This god, moreover, makes explicit this resistance to industrial civilization and its values, Ramon's Fourth Hymn, "What Quetzalcoatl Saw in Mexico", where he urges the Mexican people to give up the machines they cannot make. ${ }^{174}$

Don Ramon's vision is that human beings can not hope but to serve something, and that that something they serve must be spiritual if they are to be whole. In the civilization that is to come, the living spiritual force is the force of the dark gods, so that the emphasis is one these, but the reality is that a civilization which divides life as dramatically as industrial civilization did (between production and consumption, making and taking, love and power, mind- and blood-consciousness), or emphasizes one side of life above the other to such an extent that it fails to take into account the flip side of the coin, is a

${ }^{173}$ Lawrence, The Plumed Serpent, 163. 
civilization which is destroying itself. The cult of Quetzalcoatl, its reconnection of the people with their land and its rejection of the "love-urge" and the machinery of industrialism, its looking backwards to Aztec civilization, is like Don Ramon's accepting his dark god as his master, necessarily rejects the bifurcation inherent in Second Wave civilization. What Richard Somers had dreamed of convincing a leader to embrace, Don Ramon is making manifest, and where Richard Somers had thought wistfully of communion with his fellow men in the darkness below, Don Ramon would "pass in the quick of himself, with transfiguration, to the Morning Star, and there, there alone meet his fellow man." 175

Don Ramon's mastery having been established, he proceeds to "hold it fast" through military power, much as Lilly Rawdon had imagined it should be in Aaron's Rod. Don Cipriano is the commander of Ramon's "stormtroopers", so to speak, but he is very much unlike the returned veterans who comprised the Diggers in Kangaroo. Rather than serving the abstraction of a nation or a political ideal, Don Cipriano and his men have submitted to the greater soul of Don Ramon, the First Man of Quetzalcoatl. In fighting on behalf of Quetzalcoatl, they fight on behalf of the "God of their own manhood", a form of service that rather than being self-sacrificing, makes them complete according to the logic by which Don Ramon has himself become complete. It would therefore be more appropriate to refer to them as warriors rather than as soldiers.

Additionally, rather than Don Ramon's state and its institutions being molded by the demands of modern warfare, as had been the case of England, war is here subordinated to

${ }^{174}$ Lawrence, The Plumed Serpent, 253-257. 
the spiritual life of the state with even this most worldly of activities taking on an otherworldly character. Not being a man of the Second Wave, Don Cipriano does not presume to fight like one either. Instead of mass and technology, or principles like concentration of force and the decisive battle, what his men have is the "second strength" that comes from their new spirituality, and their strategy and tactics are what a Second Wave military thinker would likely call "unconventional".

"For us, no trench and cannon warfare. My men are no cannon-fodder, nor trenchdung. Where cannon are, we move away. Our hundreds break up, and we attack where the cannon are not ... We intend to put up no battlefront, but to attack at our own moment, and at a thousand points."176

The connection between the religious revival and wholeness, and the abandonment of the machine, is why the leader for which Richard Somers had been searching appears in underdeveloped, "unbroken" Mexico where the modern ethos invariably goes to pieces ${ }^{177}$ rather than in Australia, which could only produce a Cooley, a Callcott or a Struthers. Mexico, Don Ramon says,

"pulls you down, the people pull you down like a great weight . . . they draw you down as the earth draws down the roots of a tree, so that it may be clinched deep in soil. Men are still part of the Tree of Life, and the roots go down to the centre of the earth ... the men in Mexico are like trees, forests that the white men felled in their coming. But the roots of the trees are deep and alive and forever sending up new shoots." ${ }^{178}$

Australia, at least since its colonization from the end of the eighteenth century on, was never anything but a Second Wave country, and the "mind-consciousness" of

${ }^{175}$ Lawrence, The Plumed Serpent, 249.

${ }^{176}$ Lawrence, The Plumed Serpent, 365.

${ }^{177}$ Lawrence, The Plumed Serpent, 67. 
industrialized society had likewise flourished in America, "the great death continent" since the arrival of European settlers. ${ }^{179}$ Therefore while the roots need only the opportunity to send up shoots in Mexico, attainable through the casting off of an industrial civilization which had had only a superficial impact as yet, the machines in Australia and America would first have to be cleared away and industrialized civilization to die (in "chaos and anarchy in the name of love and equality") before life could truly begin there.

Nonetheless, life would eventually begin in Australia and America as well. Don Ramon's accomplishing everything that Lilly Rawdon and Richard Somers had hinted at suggests that the cult of Quetzalcoatl is by no means a solely Mexican phenomenon, but an expression of something elemental, the deeper truth of the one God with which people in each time and place will connect in their own way. ${ }^{180}$ Don Ramon tells Don Cipriano (in whose eyes is the "gleam of a Holy War") that

"I would like ... to be one of the Initiates of the Earth . . Every country its own Saviour... And the First Men of every people, forming a Natural Aristocracy of the World . . And in some way the world must be organically united ... in the concrete... I wish the Teutonic world would once more think in terms of Thor and Wotan ... the Druidic world ... that they ... are the Tuatha De Danaan . . . a new Hermes should come back to Mediterranean, and a new Ashtaroth to Tunis; and Mithras again to Persia, and Brahma unbroken to India, and the oldest of dragons to China." ${ }^{181}$

${ }^{178}$ Lawrence, The Plamed Serpent, 75-76.

${ }^{179}$ Lawrence, The Plumed Serpent, 73.

${ }^{180}$ Wright, 199.

${ }^{181}$ Lawrence, The Plumed Serpent, 244-245. 
Moreover, Don Ramon's influence on Kate Leslie, an Irishwoman of aristocratic family, is also suggestive of the universal significance of what Lawrence has described him achieving in The Plumed Serpent. Kate can be regarded as a representative of industrial civilization, a "mind-conscious" "modern woman" who belongs to "the AngloSaxon or Teutonic world" and has money and is "altogether free." 182 She is an "individual, and therefore not a good follower", and while she breaks with her more conventionally idealistic friends Owen and Villiers early on in the novel, it is by no means a foregone conclusion that she will submit to Ramon. ${ }^{183}$

Kate is distressed that as an individual human being, an individual woman, "she had little or no significance. As a woman on her own, she was repulsive, and even evil, to him." ${ }^{184}$ The wisdom of the old, pre-Flood world, which had so attracted Lilly in Aaron's Rod, and appeared to be embodied in Ramon's religious revival, was horrifying to her. ${ }^{185}$ Told that there is only one blood, she tried to "hold herself up, in the proud old assertion: My blood is my own." ${ }^{186}$ Kate

resists Ramon every step of the way, criticizing at times, joining forces with the pious Carlota, at times openly sceptical and contemptuous of what he is trying to do ... her reactions ... an ironical counterpoint to Ramon's actions, juxtaposing the fragmentation of the satiric and contemporary against the timeless and mythic quest for wholeness. ${ }^{187}$

${ }^{182}$ Lawrence, The Plumed Serpent, 202.

${ }^{183}$ Lawrence, The Plumed Serpent, 214.

${ }^{184}$ Lawrence, The Plumed Serpent, 386.

${ }^{185}$ Lawrence, The Plumed Serpent, 414.

${ }^{186}$ Lawrence, The Plumed Serpent, 415. 
Nevertheless, Don Ramon steadily brings her about to his position. Kate feels a great change being worked in her, one which she feels is so dramatic that it might kill her. ${ }^{188}$ No longer does she reject out of hand the idea that her blood is not her own, instead acquiescing

to the primeval assertion: The blood is one blood. We are one blood. It as the assertion that swept away all individualism and left her immersed, drowned in the grand sea of the living blood, in immediate contact with all these men and all these women. 189

The novel, however, does not end with Kate submitting to Don Ramon, a whole, integrated personality like himself. The religious transmutation that Don Ramon had achieved even before his appearance in the novel is something that Kate is still struggling toward. ${ }^{190}$ Consequently, the mood at the end of the novel is not one of "fulfillment and achievement, but of partial vision and uncertain hope." In a sense, that is how it must be. While Don Ramon has found a way to God and to wholeness, his is by no means the only path. Nevertheless, it is $a$ way, and the fact that one has been found is for Lawrence cause for optimism.

187 Vickery, 131.

${ }^{188}$ Lawrence, The Plumed Serpent, 412.

${ }^{189}$ Lawrence, The Plumed Serpent, 415.

${ }^{190}$ Vickery, 128 


\section{LIST OF REFERENCES}

Andrews, W.T. Ed. Critics on D. H. Lawrence. London: Allen and Unwin, 1971.

Balbert, Peter and Phillip L. Marcus, Ed. D.H. Lawrence: a centenary consideration. Ithaca, N.Y.: Cornell UP, 1985.

Becket, Fiona. D.H. Lawrence: the thinker as poet. New York: St. Martin's Press, 1997.

Daleski, H.M. The Forked Flame: a study of D.H. Lawrence. Evanston: Northwestern UP, 1965.

Delavenay, Emile. D.H. Lawrence: The Man and His Work. London: Heinemann, 1972.

Draper, R.P. D.H. Lawrence: The Critical Heritage. London: Routledge \& Kegan Paul Ltd., 1970.

Fernihough, Anne Ed. The Cambridge companion to D.H. Lawrence. New York: Cambridge UP, 2001.

Goodheart, Eugene. The Utopian Vision of D.H. Lawrence. Chicago: U of Chicago P, 1963.

Granofsky, Ronald. "Jews of the Wrong Sort: D.H. Lawrence and Race" Journal of Modern Literature Winter 1999-2000: 209-223.

Gregory, Horace. D.H. Lawrence: Pilgrim of the Apocalypse. New York: Grove Press, Inc., 1933.

Hough, Graham. The Dark Sun: A Study of D.H. Lawrence. New York: Capricon Books, 1956.

Humma, John B. "Of Bits, Beasts and Bush: The Interior Wilderness in D. H. Lawrence's Kangaroo" South Allantic Review. Jan. 1986, 83-100. P, 1990 .

. Metaphor and meaning in D.H. Lawrence's later novels. Columbia: U of Missouri

Hyde, G.M. D.H. Lowrence. New York: St. Martin's Press, 1990.

Ingersoll, Earl G. D.H. Lawrence, desire, and narrative. Gainesville, FL : UP of Florida, 2001.

Kermode, Frank. D.H. Lawrence. London: Fontana, 1973. 
Leavis, F.R. Thought, words and creativity: art and thought in Lawrence. New York: Oxford UP, 1976.

Mensch, Barbara. D.H. Lawrence and the Authoritarian Personality. New York: St. Martin's Press, 1991.

Niven, Alastair. D.H. Lowrence: The Novels. Cambridge: Cambridge UP, 1978.

Pinkney, Tony. D.H. Lowrence and modernism. Ist ed. Iowa City: U of Iowa P, 1990.

Poplawski, Paul. Promptings of Desire. Westport, Connecticut: Greenwood Press, 1993.

Preston, Peter and Peter Hoare. D.H. Lowrence in the modern world. New York: Cambridge UP, 1989.

Ruderman, Judith. "The 'Trilogy' That Never Was: The Rainbow, Women in Love, and Aaron's Rod" PBSA: Papers of the Bibliographical Society of America. 1980, 76-80.

Sicker, Philip. "Lawrence's Auto da fe: The Grand Inquisitor in The Plumed Serpent" Comparative Literature Studies. 1992, 417-40.

Spilka, Mark. The love ethic of D.H. Lawrence. Bloomington, Indiana: Indiana UP, 1955. $\overline{\text { Prentice-Hall, } 1963 .}$

. Ed. D.H. Lawrence: a collection of critical essays. Englewood Cliffs, N.J.:

Squires, Michael and Keith Cushman. Ed. The Challenge of D.H. Lowrence. Madison, Wisconsin: U of Wisconsin P, 1990.

Tenenbaum, Elizabeth Brody. The problematic self : approaches to identity in Stendhal, D. H. Lawrence, and Malraux. Cambridge, Mass.: Harvard UP, 1977.

Toffler, Alvin. Future Shock. New York: Random House, 1970. The Third Wave. New York: Bantam Books, 1981. Powershift. New York: Bantam Books, 1980. and Heidi Toffler. War and Anti-War. New York: Little, Brown \& Co., 1993.

Waters, Frank. "Quetzalcoatl Versus D. H. Lawrence's Plumed Serpent" Western American Literature. 1968, 103-113.

Wexler, Joyce. "Realism and Modernists' Bad Reputation" Studies in the Novel: 1999 Spring, 60-73. 
Williams, Linda Ruth. D.H. Lowrence. Plymouth: Northcote House in association with the British Council, 1997.

Worthen, John. D.H. Lawrence. New York: E. Arnold, 1991.

Wright, T.R. D.H. Lawrence and the Bible. Cambridge: Cambridge UP, 2000.

Vickery, John. "The Plumed Serpent and the Eternal Paradox" Criticism: A Quarterly for Literature and the Arts. 1963, 119-134.

Zytaruk, George J. Ed. The Letters of D.H. Lawrence. Cambridge: Cambridge U, 1981. 